\title{
The Latest Developments of the US Freedom of Navigation Programs in the South China Sea: Deregulation or Re-balance?
}

\author{
Xinjun Zhang*
}

Regarding warships, customary rules on innocent passage and freedom of navigation codified in the UNCLOS are far from being settled among State Parties. FONOPS impose the US understanding of rules on passage and navigation in each and every sea area, forcefully implementing deregulation in order for the US to create a navyfriendly environment for its worldwide mission. By implementing another agenda of carrying out the new US policy of "Pivot to Asia," the FONOPs in the South China Sea challenge the very heart of China's sovereignty, and may bring about adverse effect to the process of peaceful settlement of territorial issues and maritime disputes in the South China Sea region. China believes the US FONOPs in the South China Sea are offensive to its sovereignty. Moreover, their adverse effect to the process of peaceful settlement of territorial issues and maritime disputes in the South China Sea region cannot be ignored.

\section{Keywords}

FONOP, South China Sea, UNCLOS, Passage and Navigation, Low Tide Elevation, Artificial Island

* Associate Professor of International Law at Tsinghua University, Beijing, China. LL.B. (Fudan), Ph.D. (U. Kyoto). ORCID: http://orcid.org/0000-0001-7281-3893 The author may be contacted at: zxinjun@mail.tsinghua.edu.cn/ Address: School of Law, Tsinghua University, Beijing 100084, China. DOI: http://dx.doi.org/10.14330/jeail.2016.9.1.08 


\section{Introduction}

The South China Sea is one of the most troubled waters in the globe recently. Despite the fragility of the situation there, the US proceeded to send its Naval vessels to carry out the so-called Freedom of Navigation Programs ("FONOPs") ${ }^{1}$ to pass within 12 nautical miles ("nm") of several islands and reefs in the South China Sea. On October 26, 2015, the USS Lassen navigated near Zhubi (Subi) Reef in the Nansha (Spratly) Islands, where China launched a land reclamation project for the possible airstrip on it. Three months later, on January 30, 2016, the USS Curtis Wilbur transited within $12 \mathrm{~nm}$ of Zhongjian (Triton) Island, the south-western basepoint in the straight baseline of the Xisha (Paracel) Islands. ${ }^{2}$ In both cases, the Chinese naval vessels monitored, followed and warned US naval vessels on-site. In particular, after the USS Lassen incident the Chinese government immediately lodged protest. ${ }^{3}$

In the USS Curtis Wilbur incident, the issue is centered on war-ships' right of innocent passage, a long-standing question since the United Nations the Law of the Sea Convention ("UNCLOS") was adopted in 1982. ${ }^{4}$ Because the US is not a party of the UNCLOS, the innocent passage should be interpreted in accordance with customary international law, reflecting current State practices, as well. This issue, however, was complicated by the calculation (or miscalculation) of the US Defense Department in the USS Lassen incident, because the Subi reef, in the view of the US, is merely a low tide elevation ("LTE") that has no territorial sea of its own, whereas China has undertaken land reclamation activity for the purpose, allegedly, to turn it into an island. ${ }^{5}$

1 For an introduction to the US FONOPs in the South China Sea, see M. Green, B. Glaser \& G. Poling, The U.S. Asserts Freedom of Navigation in the South China Sea, Asia Maritime Transparency Initiative, Oct. 27, 2015, available at http://amti.csis.org/the-u-s-asserts-freedom-of-navigation-in-the-south-china-sea/ (last visited on May 11, 2016).

2 N. Panda, Return of the FONOP: US Navy Destroyer Asserts Freedom of Navigation in Paracel Islands, DiPLOMAT, Jan. 31, 2016, available at http://thediplomat.com/2016/01/return-of-the-fonop-us-navy-destroyer-asserts-freedom-ofnavigation-in-paracel-islands (last visited on May 12, 2016).

3 PRC Foreign Ministry, Vice Foreign Minister Zhang Yesui Makes Stern Representations to US over US Naval Vessel's Entry into Waters near Relevant Islands and Reefs of China's Nansha Islands, Oct. 27, 2015, available at http://www. fmprc.gov.cn/mfa_eng/wjbxw/t1310069.shtml (last visited on May 12, 2016).

4 United Nations Convention on the Law of the Sea, 1833 U.N.T.S. 3; 21 I.L.M. 1261 (1982).

5 Secretary of Defense Carter, A Regional Security Where Everyone Rises, IISS Shangri-La Dialogue, May 30, 2015, available at https://www.iiss.org/-/media/Documents/Events/Shangri-La\%20Dialogue/SLD15/Carter.pdf. See also PRC Foreign Ministry, Foreign Ministry spokesperson Hong Lei's regular press conference, Sept. 18, 2015, available $a t$ http://www.fmprc.gov.cn/mfa_eng/xwfw_665399/s2510_665401/t1298026.shtml (all last visited on May 5, 2016). 


\section{USS Curtis Wilbur Incident: the long-lasting controversy on 'innocent passage' of war-ships}

One of the objects of FONOPs is to ensure that the US warships can exercise the right of innocent passage in foreign territorial waters without prior consent from the coastal State or being subject to its requirement for prior notification. In doing so, it leaves little doubt that the manner of the passage must be in conformity to 'innocent passage.' Article 19 of the UNCLOS provides that 'innocent passage' shall be continuous and expeditious; and shall not engage in certain activities including "any exercise or practice with weapons of any kind," or "the launching, landing or taking on board of any aircraft." 6

In the USS Curtis Wilbur incident, China did not question the manner of the passage, but condemned its entering into the Chinese territorial sea without prior approval from China. The spokesperson from the Chinese Foreign Ministry stated:

According to the Law of the People's Republic of China on the Territorial Sea and the Contiguous Zone, foreign ships for military purposes shall be subject to approval by the Government of the People's Republic of China for entering the territorial sea of the People's Republic of China. The US navy vessel violated the relevant Chinese law and entered China's territorial sea without authorization. ${ }^{7}$

Articles 17 and 19 of the UNCLOS mainly deal with the question of prior consent or notification required for warships before exercising innocent passage in foreign territorial waters as an issue of interpretation. Throughout the first and the third UN Conference on the Law of the Sea, each bloc of the West, the East (socialist) and the Third World maintained its own stance on this point, but they have not yet fully settled conflicting block views. ${ }^{8}$

The regime of innocent passage under the UNCLOS has been basically produced by codifying customary international law. However, the contemporary principle of customary innocent passage was not so clear regarding foreign warships. In the Corfu Channel case, e.g., the International Court of Justice ("ICJ") declined to enter into a consideration of a general question whether or not a State has the right to

6 UNCLOS art. 19(2).

7 PRC Foreign Ministry, Foreign Ministry Spokesperson Hua Chunying's Remarks on US Navy Vessel's Entry into Territorial Waters of Zhongjian Dao of China's Xisha Islands, Jan. 30, 2016, available at http://www.fmprc.gov.cn/ mfa_eng/xwfw_665399/s2510_665401/2535_665405/t1336822.shtml (last visited on May 11, 2016).

8 M. Shaw, International Law 510 (5th ed. 2003). 
send warships in time of peace through foreign territorial waters, although innocent passage of warships through straits (within the territorial sea of a strait state) used for international navigation did not require advance authorization of the coastal (strait) State. ${ }^{9}$

Since the adoption of the UNCLOS in 1982, State parties have maintained a sharp difference on the issue of innocent passage of warships. On this point, although the UNCLOS prohibits reservation, Article 310 allows State Parties to make declarations or statements with a view to harmonize their laws and regulations with the provisions of this Convention, thus enabling auto-interpretations. Article 310 was drafted and inserted, arguably, to leave space for interpretation considering that many provisions reached on the basis of consensus during the ten year long negotiation are ambiguous. ${ }^{10}$ One of them is innocent passage. Pursuant to Article 310, many States insisted that in order for warships to exercise passage through territorial sea, either advance approval (e.g., Iran, Oman, Yemen, China and Algeria), or prior notification (e.g., Egypt, Malta, Croatia, Finland, Sweden, Serbia and Montenegro, and Bangladesh) is necessary. ${ }^{11}$ Accordingly, their domestic laws and regulations regarding innocent passage will not change even after ratification. Some States have the same regulation set out in their domestic laws and legislations without issuing such declarations or statements, while others stated that either the UNCLOS permits foreign warships innocent passage without prior authorization, or such prior consent or notification is incompatible with the UNCLOS (e.g., Argentina, Chile, Netherlands, Germany and Italy). ${ }^{12}$

The 1988 Black Sea Bumping incident and the 1989 USSR-US Joint Statement added fuel to the debate. In the 1988 incident, the US naval vessels exercising FONOPs in the Soviet Union's territorial waters were intercepted and then collided with Soviet naval vessels which took measures against the US warships allegedly in violation of the USSR's domestic regulation of innocent passage. ${ }^{13}$ Notwithstanding that the Soviet Union and the US were non-parties to the UNCLOS at that time (Russian Federation ratified in 1997), the two countries were of the view that in particular Part II, Section 3 of the UNCLOS reflects the customary international law

9 Corfu Channel case (U.K. v. Alb.), Judgment, 1949 I.C.J. 28 \& 30 (Apr. 9), available at http://www.icj-cij.org/docket/ files/1/1645.pdf (last visited on May 12, 2016).

10 For details, see V United Nations Convention on the Law of the Sea 1982: A Commentary 224 (1989).

11 UN Division for Ocean Affairs and the Law of the Sea, Declarations and Statements, available at http://www.un.org/ Depts/los/convention_agreements/convention_declarations.htm (last visited on May 11, 2016).

12 Id.

13 J. Rolph, Freedom of Navigation and the Black Sea Bumping Incident: How "innocent" Must Innocent Passage Be?, 135 Military L. Rev. 139-44 (1992). 
governing innocent passage. ${ }^{14}$

Mysteriously, State responsibility was raised by neither the US nor the Soviet Union for the damages caused by an allegedly wrongful act regarding innocent passage. Instead, the two countries, only after the incident, reached an agreement on the interpretation on the rule concerning innocent passage, particularly in relation to worships' passage (hereinafter 1989 Joint Statement). In the Uniform Interpretation of the Rules of International Law governing Innocent Passage through the Territorial Sea attached to the 1989 Joint Statement, the two naval superpowers agreed:

All ships, including warships, regardless of cargo, armament or means of propulsion, enjoy the right of innocent passage through the territorial sea in accordance with international law, for which neither prior notification nor authorization is required. ${ }^{15}$

This episode vividly shows that the then customary rule on innocent passage was not clear as to whether foreign warships can enter territorial waters of costal States without prior notification or authorization. It might otherwise be highly risky that one side in the incident, depending on how the customary rule had been defined, should be held responsible. Before reaching this Uniform Interpretation, the Soviet position on this matter was actually in line with that of the developing world, maintained during negotiation for drafting the text on innocent passage of the 1958 Convention on the Territorial Sea and Contiguous Zone in the first UN Conference on the Law of the Sea. ${ }^{16}$ The two naval powers, only by this agreement, managed to clarify the rule on innocent passage regarding warships.

This Uniform Interpretation will be definitely applied lex specialis between them. But it is not certain how much it will contribute to developing the customary rule on the innocent passage of foreign warships reflected in the provisions of the UNCLOS. The practice of non-parties, subsequent to the adoption of a treaty is not without value in affirming an emerging custom rising out of that treaty. ${ }^{17}$ It is absurd to find that, amid the huge difference in the subsequent practice of State Parties, non-parties' practice prevails in the matter of treaty interpretation of a codified customary rule.

14 See Uniform Interpretation of the Rules of International Law Governing Innocent Passage through the Territorial Sea, 14 LAw OF tHE SEA BulL. 13 (1989), available at http://www.un.org/depts/los/doalos_publications/LOSBulletins/ bulletinpdf/bulE14.pdf (last visited on May 11, 2016).

15 Id. art. 2.

16 Supra note 8 , at 510.

17 North Sea Continental Shelf (F.R.G. v. Neth. v. Den.), Judgment, 1969 I.C.J. 43-4, 76 (Feb. 20), available at http:// www.icj-cij.org/docket/files/52/5561.pdf (last visited on May 12, 2016). 
As different positions regarding foreign warships' innocent passage among State Parties are often indicated in their interpretative statements and domestic laws, a decision by the courts or tribunals referred to in Article 287 of the UNCLOS could help to render a clear and authoritative interpretation. However, the chance of realization of this hope is dim. In the Bangladesh/Myanmar case, the International Tribunal for the Law of the Sea ("ITLOS"), by taking note of Bangladesh's previous commitment of "free and unimpeded navigation" for Burmese vessels, set up a sui generis right of passage for Myanmar and in the territorial water of the Saint Martin's Island (which was recognized as belonging to Bangladesh), which Bangladesh has a legal obligation to respect. ${ }^{18}$ Against this backdrop, Bangladesh made its interpretative statement pursuant to Article 310 of the UNCLOS explicitly requiring prior notification for the foreign warships to enter its territorial waters. ${ }^{19}$

Here, Bangladesh's commitment and the following obligation shall be considered as being permissive and different from what Bangladesh acknowledges in its interpretation of 'innocent passage' under the Convention, because it would have otherwise been redundant for the Tribunal to obtain such a commitment. In helping to establish such a sui generis right of passage for Myanmar in this maritime area, the ITLOS avoided the classic conflict in the interpretation of 'innocent passage' provided for in the UNCLOS in relation to foreign warships. ${ }^{20}$

Overall, in the present state of affairs, international law on innocent passage in relation to foreign warships seems to legitimize auto-interpretations from both sides. China has traditionally associated its position with developing countries on this matter, explicitly requiring foreign warships to obtain advance authorization to enter its territorial waters. ${ }^{21}$ China, however, may have another position on this matter, as its naval power grows. It may follow what the Soviet Union did in 1989. Nonetheless, future events have nothing to do with ongoing incidents between the US and China in the Chinese territorial waters of the South China Sea.

18 Dispute concerning delimitation of the maritime boundary between Bangladesh and Myanmar in the Bay of Bengal (Bangl. v. Myan.), Judgment (The Bay of Bengal Judgment), 2012 ITLOS $\uparrow \uparrow$ 174-6 (Mar. 14), available at www.itlos. org/fileadmin/itlos/documents/cases/case_no_16/1-C16_Judgment_14_02_2012.pdf (last visited on May 11, 2016).

19 Bangladesh Declaration upon ratification, July 27, 2001, at 3 \& 4, available at http://www.un.org/Depts/los/ convention_agreements/convention_declarations.htm\#Bangladesh Upon ratification (last visited on May 11, 2016).

20 Xinjun Zhang, The ITLOS judgment in the Bay of Bengal case between Bangladesh and Myanmar, 12 CHINESE J. INT'L L. 268 (2012).

21 The Law on the Territorial Sea and the Contiguous Zone of the People's Republic of China, adopted at the 24th meeting of the Standing Committee of the National People's Congress, at art. 6, Feb. 25, 1992, available at http://www.un.org/ depts/los/LEGISLATIONANDTREATIES/PDFFILES/CHN_1992_Law.pdf (last visited on May 12, 2016). 


\section{The USS Lassen Incident: unwanted 'innocent passage' within $12 \mathrm{~nm}$ of Subi Reef}

Unlike Zhongjian (Triton) Island, the Zhubi (Subi) reef is taken by the US as a lowtide elevation ("LTE”). A LTE, according to Article 13 of the UNCLOS, does not have territorial sea of its own unless it is wholly situated at a distance within the breadth of the territorial sea from the mainland or an island. ${ }^{22}$ In other words, a LTE may be used as a basepoint in drawing a baseline to 'bump out' the territorial sea, which makes it different from mid-ocean LTE or non-offshore LTE as defined in the subsequent section. ${ }^{23}$

It is widely reported that the USS Lassen's passage within the $12 \mathrm{~nm}$ of the Subi Reef was in the manner of innocent passage. As the Lassen's fire control radar was shut off, the helicopters remained on board through its passage within $12 \mathrm{~nm}$ and the accompanying surveillance flight was kept outside of the $12 \mathrm{~nm}$ during the operation. ${ }^{24}$ Nevertheless, the manner of warship passage has to be examined case by case, because preparation for exercise or practice with weapons might be permissible in some circumstances. ${ }^{25}$ At the least, turning off the fire control radar can be acknowledged by the US simply following the agreed manner between the US and China, in case the Navies meet at the sea. ${ }^{26}$

Despite rumors, no Chinese official sources confirm that the Chinese Naval vessels engaged in monitoring, following or warning USS Lassen; in their communications, received any signals from the latter indicating that it was exercising innocent passage. The statement of the Chinese Foreign Minister spokesperson regarding this incident is mixed. The spokesperson maintained:

The USS Lassen illegally entered waters near relevant islands and reefs of China's Nansha Islands without the permission of the Chinese government, ... relevant actions by the US naval vessel threatened China's sovereignty and security interests, put the personnel and facilities on the islands and reefs at risk and endangered regional peace

22 UNCLOS art. 13.

23 See infra note 33 and the accompanying text.

24 A. Klein \& M. Rapp-Hooper, What Did The Navy Do In the South China Sea?, Lawfare, Nov. 4, 2015, available at https://www.lawfareblog.com/what-did-navy-do-south-china-sea (last visited on May 12, 2016).

25 Supra note 9, at 30-2. [Emphasis added]

26 Document: Conduct for Unplanned Encounters at Sea, USNI News, June 17, 2014, available at https://news.usni. org/2014/06/17/document-conduct-unplanned-encounters-sea (last visited on May 12, 2016). 
and stability. ${ }^{27}$

Despite of insisting on a need for permission, the spokesperson avoided mentioning the territorial sea of Subi Reef, but stressed the threatening of and damage to China's sovereignty and security interests in the Subi Reef and its adjacent water.

The American sources unofficially maintain that USS Lassen's was exercising innocent passage within the $12 \mathrm{~nm}$ Subi Reef. This was, however, criticized by the US commentators that by asserting innocent passage within $12 \mathrm{~nm}$ of the Subi Reef, the US acquiesced that Subi Reef has a territorial sea. ${ }^{28}$ Meanwhile, other US commentators justified the passage on the basis of the 'bump out' clause in Article 13 of the UNCLOS; they assert that since the Subi Reef is located at a distance within $12 \mathrm{~nm}$ of a nearby island which is above water at high tide, it can be used as a basepoint for the nearby islands' territorial sea so that Subi Reef itself could generate a $12 \mathrm{~nm}$ territorial sea. ${ }^{29}$ The American commentators referred to Sandy Cay as the 'nearby island' in making this argument.

After nearly two months of silence, the Secretary of Defense Ash Carter sent a letter to Sen. John McCain (R-Ariz.) concerning USS Lassen's innocent passage, which said:

[I]f it is located within 12 nautical miles of another geographic feature that is entitled to a territorial sea - as might be the case with Sandy Cay - then the low-water line on Subi Reef could be used as the baseline for measuring Sandy Cay's territorial sea. In other words, in those circumstances, Subi Reef could be surrounded by a 12-nautical mile-territorial sea despite being submerged at high tide in its natural state. Given the factual uncertainty, we conducted the FONOP in a manner that is lawful under all possible scenarios to preserve U.S. options should the factual ambiguities be resolved, disputes settled, and clarity on maritime claims reached. ${ }^{31}$

27 PRC Foreign Ministry, Lassen's Entry into Waters near Relevant Islands and Reefs of China's Nansha Islands Oct. 27,

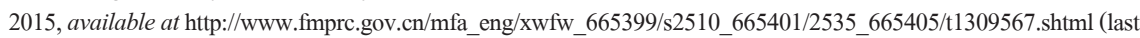
visited on May 12, 2016).

28 Supra note 24. See also J. Smith, An Innocent Mistake, Foreign AfF., Dec. 3, 2015, available at https://www. foreignaffairs.com/articles/china/2015-12-03/innocent-mistake (last visited on May 12, 2016).

29 B. Glaser \& Peter A. Dutton, The U.S. Navy's Freedom of Navigation Operation around Subi Reef: Deciphering U.S. Signaling, NAT'L INTEREST, Nov. 6, 2015, available at http://nationalinterest.org/feature/the-us-navy\%E2\%80\%99sfreedom-navigation-operation-around-subi-reef-14272 (last visited on May 12, 2016).

30 Id. The authors point out that Sandy Cay is an unoccupied feature near Subi, and it should not be confused with the Viet Nam occupied Sand Cay which is irrelevant to the 'bumping out' of territorial sea in relation to Subi Reef.

31 Document: SECDEF Carter Letter to McCain On South China Sea Freedom of Navigation Operation USNI NEwS, Jan. 5, 2016, available at https://news.usni.org/2016/01/05/document-secdef-carter-letter-to-mccain-on-south-chinasea-freedom-of-navigation-operation (last visited on May 12, 2016). 
As shown at the letter, the US takes an official position that, even assuming that the USS Lassen conducted FONOP in a manner of innocent passage within $12 \mathrm{~nm}$ of Subi Reef, the water may be part of territorial sea bumping out from Sandy Cay.

It is curious why the Americans, in making justifications based on the 'bump out' clause, picked the uninhabited Sandy Cay, turning blind to Subi's contiguous Thitu Island, the second largest of the naturally occurring Spratly Islands. ${ }^{32}$ Taking the reefs and LTEs geographically scattered within its $12 \mathrm{~nm}$ including the Subi Reef into consideration, the Subi reef is part of Thitu Island and reefs, which consists of Thitu Island, Tiezhi Jiao (Thitu reef), Tiezhi Shuidao (Thitu trough), Meijiu Jiao, Tiexian Jiao (Sandy Cay) and Subi Reef.

Arguably, the US could not but refer to Sandy Cay in making the above justification. Thitu Island is inconvenient to mention because it is occupied by the Philippines, one of its allies. With this justification, the US could avoid acknowledging that the Subi Reef has territorial sea of its own; it, however, attracts consequences that may seriously damage the FONOP conducted by USS Lassen's in the other scenario.

Even though the US qualifies the USS Lassen's passage in the vicinity of the Subi Reef as innocent through the territorial sea of Thitu Island and reefs by applying the 'bump out' clause, Chinese naval vessels engaging in monitoring and following the USS Lassen manifestly did not exercise innocent passage in the same route. Today, the US does not take sides in sovereignty disputes over the Spratly Islands. By conducting FONOP in this unique geographic area, the US may have encouraged China to exercise jurisdiction within $12 \mathrm{~nm}$ of Thitu Island, which in the Chinese view is illegally occupied by the Philippines. It would be even worse would if the Philippines forgot to lodge a protest as a military ally of the US playing a role in the act of the FONOPs in the South China Sea.

32 James Kraska disqualified Sandy Cay as 'island' that enables parasitic LTE to generate territorial sea but no reference was made to Thitu Island. In an article published in the latest, he admitted that: "Subi Reef ... positioned only 14 kilometers from the Philippine Thitu Island." See R. Pedrozo \& J. Kraska, Can't Anybody Play This Game? US FON Operations and Law of the Sea, LAWFARE, Nov. 17, 2015, available at https://www.lawfareblog.com/cant-anybodyplay-game-us-fon-operations-and-law-sea\#; J. Kraska, Forecasting the South China Sea Arbitration Merits AwARD, Apr. 27, 2016, available at http://maritimeawarenessproject.org/2016/04/27/forecasting-the-south-chinasea-arbitration-merits-award (all last visited on May 12, 2016). 


\section{Exercise of Freedom of Navigation by FONOPs around the Chinese 'Non-offshore' LTEs in the South China Sea}

The US may choose LTEs lying outside the range of $12 \mathrm{~nm}$ from any islands nearby (hereinafter non-offshore LTE) as a target for its future FONOPs in the Spratlys. Mischief Reef may be a good candidate. ${ }^{33}$ FONOPs will be conducted within the 12 $\mathrm{nm}$ boundary in the way that freedom of navigation is unambiguously exercised in a normal pattern. The US would maintain that neither prior permission, nor even the 'innocent' passage is needed to justify FONOPs there. Those FONOPs will be conducted in order to reject any possible setting of a territorial water boundary for non-offshore LTEs in the Spratly Islands, where there are land reclamation activities attempting to change LTEs into islands.

China adopted the Law on the Territorial Sea and the Contiguous Zone in 1992 (hereinafter 1992 Chinese Law) asserting that the Nansha Islands, like the Xisha Islands and other Chinese oceanic archipelagos (Qundao in Chinese) in the South China Sea, are part of Chinese territory, while the Chinese territorial sea refers to the waters adjacent to its territorial land. ${ }^{34}$ The law also determined that China would employ the straight baseline system for delimiting its territorial sea, extending $12 \mathrm{~nm}$ from that baseline. ${ }^{35}$

In May 1996, China designated straight baselines for the Xisha Islands, in their entirety, by joining several islands and reefs including Zhongjian (Triton) Island, ${ }^{36}$ which was involved in the USS Curtis Wilbur Incident. China, however, has not yet drawn baselines for its Nansha Islands, let alone publicizing those baselines or the outer limit of territorial sea. ${ }^{37}$

33 G. Poling, South China Sea Fonop 2.0: A Step in the Right Direction, Asia Maritime Transparency Initiative, Feb. 2, 2016, available at http://amti.csis.org/south-china-sea-fonop-2-0-a-step-in-the-right-direction (last visited on May 12, 2016).

341992 Chinese Law art. 2.

35 Id. art. 3.

36 Declaration on Territorial Sea Baseline of the People's Republic of China of May 15, 1995, available at http://www. un.org/Depts/los/LEGISLATIONANDTREATIES/PDFFILES/DEPOSIT/chn_mzn7_1996.pdf (last visited on May 12, 2012).

37 UNCLOS art. 16. 
Figure 1: Straight baselines around Xisha (Paracel) Islands ${ }^{38}$

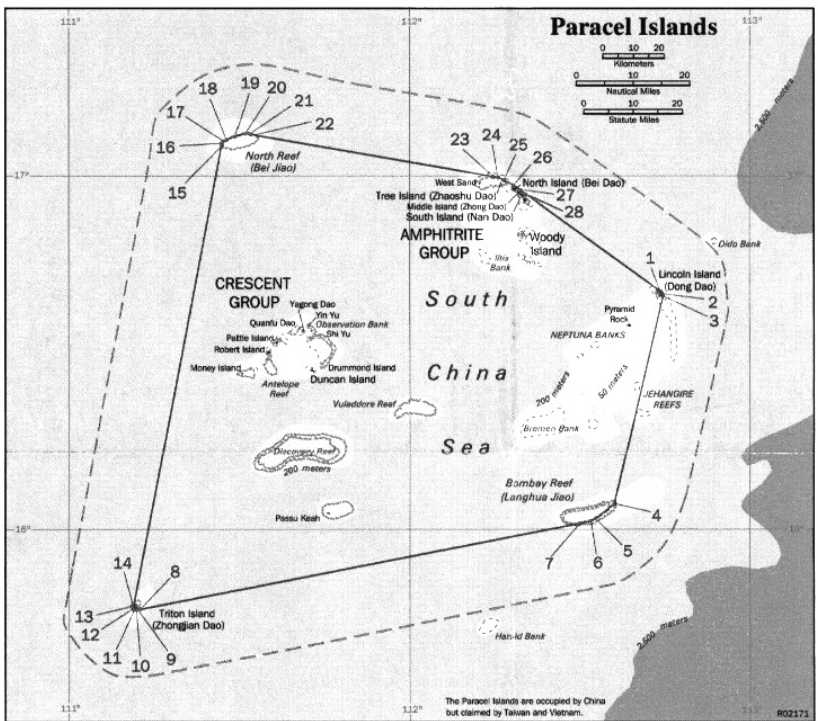

It is not yet known as to when and how China will designate a straight baseline for its Nanasha Islands. Considering the Chinese position of enjoying the "sovereignty over the Nansha Islands in its entirety," 39 China is expected to set up a straight baseline enclosing each and every maritime feature of the Nansha Islands in the foreseeable future. Today however, it is not easy for China to draw such straight baselines for the Nansha Islands, as China and the ASEAN States have committed to each other under the 2002 Declaration on the Conduct of Parties in the South China Sea ("DOC") which requires parties to "undertake to exercise self-restraint in the conduct of activities that would complicate or escalate disputes." 40 Technically, it is not very easy for China to find appropriate islands and reefs on the outskirts of the Nansha Islands in order to join with straight lines enclosing all features of the Nansha Islands. ${ }^{41}$

38 US Dept. of State, 117 Limits in the Seas: Straight Baselines Claim: China 17: annexed map (July 9, 1996), available at http://www.state.gov/documents/organization/57692.pdf (last visited on May 12, 2012).

39 Position Paper of the Government of the People's Republic of China on the Matter of Jurisdiction in the South China Sea Arbitration Initiated by the Republic of the Philippines, ๆ 20, Dec. 7, 2014, available at http://www.fmprc.gov.cn/ mfa_eng/zxxx_662805/t1217147.shtml (last visited on May 12, 2016).

40 Declaration on the Conduct of Parties in the South China Sea, art. 5, available at http://www.asean.org/?static post=declaration-on-the-conduct-of-parties-in-the-south-china-sea-2 (last visited on May 12, 2016).

41 For the LTEs not falling into $12 \mathrm{~nm}$ of a nearby island to be chosen as base points, UNCLOS only permits two 
Nevertheless, had China filled the legal gap by actually drawing a straight baseline for the Nansha Islands, the arguments regarding FONOPs conducted in the whole Spratly region would have resulted in an endless debate about the legality of the Chinese application of straight baseline in this area. A potential point of the American argument is similar to that in the USS Curtis Wilbur incident. But regardless of straight baselines for the Nansha Islands as a whole, it is untenable for the US to deny China's claim over the territorial sea around the Nansha Islands completely, ${ }^{42}$ because at least each of the individual Chinese island in the Spratly Islands has a territorial sea of its own with a breath of $12 \mathrm{~nm}$ as determined by the 1992 Chinese Law. Territorial sea must exist ipso facto and ab initio; the lack of publicity and non-deposition of charts or lists of geographical coordinates do not make any difference in this matter.

Consequently, the suggested US FONOPs to be carried out in the vicinity of nonoffshore LTEs in the Spratly Islands raises an imminent question: whether or not and to what extent a State can enjoy freedom of navigation in the vicinity of an LTE occupied by another State who is undertaking land reclamation activities for the purpose of enhancing its sovereignty over it?

The US explicitly points out that such LTE does not have territorial sea of its own regardless of land reclamation. Mr. Carter said:

[O]ne thing is clear: under the law of the sea, China's land reclamation cannot create a legal entitlement to a territorial sea, and does not change our legal ability to navigate near it in this manner. We believe that Subi Reef, before China turned it into an artificial island, was a low-tide elevation and that it therefore cannot generate its own entitlement to a territorial sea. ${ }^{43}$

If China does not fill the legal gap of its domestic law leaving each and every maritime feature of Nansha Islands without straight baselines, Carter's argument would be absolutely correct because a non-offshore LTE does not have a territorial sea of its own irrespective of land reclamation made to that LTE. Such land reclamation does not make up for the legal status of non-offshore LTE not entitled to a territorial sea. ${ }^{44}$

circumstances as exceptions. (1) lighthouses or similar installations which are permanently above sea level have been built on them; and (2) the drawing of baselines to and from such elevations has received general international recognition. See UNCLOS art. 7 (4).

42 Supra note 31. See also Pedrozo \& Kraska, supra note 32.

43 Supra note 31.

44 In the drawing of straight baseline, a non-offshore LTE may generate its own entitlement to a territorial sea under circumstance of two exceptions: lighthouses or LTEs having received general international recognition. See UNCLOS 
The problem is whether such land reclamation changes non-offshore LTEs into artificial islands, although it cannot change them into natural islands. Artificial islands are not islands under international law; they have no territorial sea of their own. ${ }^{45}$ In this context, it does not make sense to change a LTE into an artificial island. In relation to freedom of navigation, the UNCLOS allows the owner(s) of an artificial island to set a safety zone no more than 500 meters wide or otherwise agreed. ${ }^{46}$ There is no such regulation in international law for LTEs, however.

The author would argue that construction of artificial islands and land reclamation in LTEs are completely different projects with different legal connotations. The term, 'artificial islands' in the UNCLOS is not defined, but is set into the same category with 'installations' and 'structures, ${ }^{47}$ which are rooted in and associated with continental shelf. ${ }^{48}$ Installations thus refer to construction works in the seabed rather than over LTEs. Moreover, Article 60, paragraph 7 of the UNCLOS provides that: "Artificial islands, installations and structures and the safety zones around them may not be established where interference may be caused to the use of recognized sea lanes essential to international navigation." 49 This is unlikely to apply to LTEs which, by their very nature, sea lines avoid. In addition, Article 60 also prescribes due notice for the construction of artificial islands, installations and structures, or even removal of the same. ${ }^{50}$ However, such notice for the safety of navigation is not necessary in the case of construction in a LTE already marked in the charts, and removal of a LTE is physically impossible. The view that land reclamation in a LTE turning it into an artificial island also seems inaccurate given these considerations.

Even in this regard, there remains a question as to the legal significance of land reclamation over LTEs. International law recognizes 'accretion' through natural causes but not artificial fill upon the land as a means of territorial acquisition. ${ }^{51}$ Land reclamation, in general State practice, often starts from sea shores and extends seawards, but is unlikely to extend beyond the outer limit of the territorial Sea. Land reclamation within a State's territorial sea can thus hardly be taken as 'accretion' in the context of territorial acquisition. It is simply meaningless when occurring within

art. 7 (4). Mere Land reclamation does not seem to give rise to the exceptions.

45 UNCLOS art. 60 (8).

46 Id. art. $60(5)$.

47 Id. art. 60 (1).

481958 Convention on the Continental Shelf, 499 U.N.T.S. 7302, art. 5.

49 UNCLOS art. 60(7).

50 Id. art. 60 (3).

51 R. Anand, Accretion, in Max Plank Encyclopedia of Public International LaW available at http://opil.ouplaw.com/ view/10.1093/law:epil/9780199231690/law-9780199231690-e1372 (last visited on May 12, 2016). 
the territorial sea of a State. More importantly, this type of artificial construction shall not form part of coast, ${ }^{52}$ which may be used for the re-drawing of baseline resulting in moving seaward the outer limit of a state's territorial sea. In a word, land reclamation does not offer a state a legal basis for territorial acquisition by the means of 'accretion.'

Following this, it can be said that land reclamation in LTEs in the Spratly Islands cannot be seen as 'accretion'. Moreover, if the Chinese enclose each and every one of the LTEs by using a straight baseline for its Nansha Islands, 'accretion' by means of land reclamation in these LTEs will also become meaningless.

The legal and political implication of the Chinese land reclamation in LETs in the Spratly Islands, in addition to stiffening up the garrison thereon, is to display China's sovereignty over the Spratly Islands suffering from illegal occupation by foreign States. It is a practical move for China to take for claiming the Nansha Islands in its entirety, but remains debatable for claiming sovereignty over individual LTEs. Indeed, China cited two controversial decisions made by ICJ addressing the question of whether LTEs can be subject to appropriation. ${ }^{53}$

The author now comes back to the central question whether or not and to what extent a State can enjoy freedom of navigation through the vicinity of a non-offshore LTE over which another State occupies and undertakes land reclamation activities for enhancing its sovereignty over it. The UNCLOS is clear that land reclamation or garrisoning for the purpose of display of sovereignty does not enable a LTE to generate its own entitlement to a territorial sea. Nevertheless, the UNCLOS does not prescribe either for the 'zoning' of such LTEs through which a State attempts to appropriate LTEs with various means. If international law does not prohibit appropriating non-offshore LTEs, freedom of navigation would wither at a zone around the LTEs set by the State for self-help and self-defense. Even if non-offshore LTEs are not subjects for appropriation, as long as activities in the LTEs are not

52 UNCLOS art. 11.

53 China argues: "In its 2001 Judgment in Qatar v. Bahrain, the ICJ explicitly stated that, "International treaty law is silent on the question whether low-tide elevations can be considered to be 'territory." Nor is the Court aware of a uniform and widespread State practice which might have given rise to a customary rule which unequivocally permits or excludes appropriation of low-tide elevations." See Maritime Delimitation and Territorial Questions between Qatar and Bahrain (Qatar v. Bahr.), Judgment, 2001 I.C.J. 101-2, 205 (Mar. 16), available at http://www.icj-cij.org/docket/index.php? sum $=443 \& \mathrm{p} 1=3 \& \mathrm{p} 2=3 \& \mathrm{case}=87 \& \mathrm{p} 3=5$; In its 2012 Judgment in Nicaragua v. Colombia, while the ICJ stated that "low-tide elevations cannot be appropriated" See also Territorial and Maritime Dispute (Nicar. v. Colom.), Judgment, 2012 I.C.J. 641, ๆ 26 (Nov. 19), available at http://www.icj-cij.org/docket/index.php?p1=3\&p2=3\&case=124\&code= nicol\&p3=4 (all last visited on May 12, 2016). It did not point to any legal basis for this conclusory statement. Nor did it touch upon the legal status of low-tide elevations as components of an archipelago, or sovereignty or claims of sovereignty that may have long existed over such features in a particular maritime area." See supra note 39, at 92. 
forbidden (albeit meaningless in a mid-ocean LTE), a safety zone equivalent to that of artificial islands or even a defensive 'bubble zone' ${ }^{54}$ in the case of a garrisoned LTE may be legitimately set up to which freedom of navigation may yield.

\section{Conclusion}

One important goal of the US FONOPs is to de-regulate passage or navigation in maritime areas where the UNCLOS sets out rules, it tries to create a navyfriendly environment for its world-wide mission. As a naval superpower out of the UNCLOS, the US nonetheless remains keen to fully exercise its interests in free passage and navigation under the UNCLOS to support the American interest in the process of de-regulation. It would be more economic and peaceful if the US joined the UNCLOS and put these issues to rest within the mechanism of international law. As an emerging naval power within the UNCLOS, China may not be as stubborn, but seek to re-interpret the UNCLOS rules on passage and navigation in various maritime areas.

However, one may not overlook other agendas that the US sets for the FONOPs in the South China Sea. They are carrying out the new American policy of "Pivot to Asia." 55 Unfortunately, the US FONOPs are challenging China's core interest in the South China Sea not merely for the free regulations of passage or navigation, but for the very heart of sovereignty, which is beyond negotiation. China keeps the vivid memory of a hundred year's humiliation before and after the early twentieth century during which its sovereignty was repeatedly infringed by imperialists. As China opposes this kind of FONOPs carried out by the US in the South China Sea, it will resolutely defend its sovereignty over the Spratly Islands.

While the US has believed that its FONOPs are to enforce rule of law at the sea, legal analysis better supports China's position that the US FONOPs in the South China Sea are offensive to its sovereignty. Moreover, the adverse effect to the process of peaceful settlement of territorial issues and maritime disputes in the South China Sea region cannot be ignored. Both nations should carefully exercise their actions in

54 M. Schmitt, Arial Blockades in Historical, Legal and Practical Aspects, in Essays on LAW AND War at the FaUlt Lines 213 (M. Schmitt ed., 2012).

55 For details on the Pivot to Asia policy, see Eric Yong Joong Lee, Trans-Pacific Partnership (TPP) as a US Strategic Alliance Initiative under the G2 System: Legal and Political Implications, 8 J. EAST AsIA \& INT'L L. 337-9 (2015), available at http://yijuninstitute.blogspot.kr/2015/12/trans-pacific-partnership-tpp-as-us.html (last visited on May 12, 2016). 
182 Xinjun Zhang

the most diplomatic manner following international law. 